\title{
TP63 wt Allele
}

National Cancer Institute

\section{Source}

National Cancer Institute. TP63 wt Allele. NCI Thesaurus. Code C91792.

Human TP63 wild-type allele is located in the vicinity of $3 q 28$ and is approximately $266 \mathrm{~kb}$ in length. This allele, which encodes tumor protein 63 , is involved in the modulation of both apical ectoderm development and gene transcription. Mutation of the gene is associated with cervical, colon, head and neck, lung and ovarian cancers and numerous congenital disorders caused by aberrant ectodermal development and differentiation. 